\title{
PERCEPÇÃO DOS CONTABILISTAS DOS ESCRITÓRIOS DE CONTABILIDADE DE TANGARÁ DA SERRA - MT EM RELAÇÃO À ÉTICA E O RECONHECIMENTO DA CLASSE CONTÁBIL
}

\author{
Elizeu Martins da Silva ${ }^{1}$ \\ Marcelo Evandro Alves ${ }^{2}$
}

\section{RESUMO}

O artigo teve como objetivo identificar a percepção dos contabilistas dos escritórios de contabilidade de Tangará da Serra - MT em relação à ética e o reconhecimento da classe contábil. A metodologia empregada foi baseada na pesquisa de campo, e como amostras os contabilistas dos escritórios de contabilidade de Tangará da Serra. A coleta de dados foi realizada por meio de questionário desenvolvido a partir do referencial teórico da pesquisa, os questionários foram entregues pessoalmente para cada integrante da amostra. O questionário foi constituído em duas partes: perguntas de caráter censuário, para definir o perfil dos respondentes, e perguntas relacionadas à maneira como os contabilistas enxergam o reconhecimento da classe e a percepção em relação à ética. Foram traçados diante dos resultados obtidos com a pesquisa, as virtudes indispensáveis para o desempenho profissional ético, respondido pelos entrevistados como maior importância a honestidade, transparência e sigilo. Foi perguntado se o entrevistado considera ser ético, todos responderam que sim e na grande maioria assumem que utilizam o código de ética do contabilista sempre na tomada de decisões. Quando questionados a respeito da remuneração, apontaram que deveria ser mais alta e também relatam em maioria que ela não traz estabilidade e segurança financeira. Diante da experiência que possuem enfatizam que a classe contábil não é reconhecida/valorizada, e relatam os principais pontos necessários para o reconhecimento da classe contábil dentre eles: a união da classe, tabela de preço dos serviços, maior fiscalização do Conselho e a melhora do nível de conhecimento dos profissionais da classe.

Palavras-chaves: contabilidade, ética, reconhecimento/valorização, classe contábil.

\section{INTRODUÇÃO}

A sociedade necessita cada vez mais de controles e de informações abertas, completas e precisas sobre os meios de produção, empresas e capital, e a contabilidade é a ciência que possui todas as ferramentas e qualidades para atender a essas necessidades (CECCONELLO et al, 2003).

Com o processo de globalização, o desenvolvimento econômico e as transações de capital, a importância do profissional contábil no contexto econômico do país tornou-se evidente. Essa evidência é responsável por trazer ao profissional maior responsabilidades no exercício de sua atividade, porquanto se tornou gestor de informações, sendo assim seus relatórios, sua conduta devem ser pautados em padrão ético profissional.

1 Acadêmico do curso de Ciências Contábeis da UNEMAT - Campus de Tangará da Serra, e-mail: elizeu_ramos@hotmail.com.

2 Professor do curso de Ciências Contábeis da UNEMAT - Campus de Tangará da Serra, e-mail: marcelo.evandro@unemat.br 
Percepção dos contabilistas dos escritórios de contabilidade de Tangará da Serra - MT em relação à ética e o reconhecimento da classe contábil

Elizeu Martins da Silva

Marcelo Evandro Alves

Demanda-se mais transparência em todos os atos, exige-se do contador que exerça sua profissão com competência técnica e aplicação das regras inerentes à Ciência Contábil. Ser ético, enquanto profissional, significa agir em concordância com as normas e os princípios que regem uma profissão.

É trabalho difícil manter-se ético numa época em que as empresas lutam de forma árdua, e buscam alternativas para reduzir gastos, decorrentes da alta carga tributária a que estão sujeitas. É de responsabilidade do contador apresentar alternativas lícitas para condução dos negócios de seu cliente ou empregador e oferecer-lhe serviços de qualidade e confiabilidade (CRUZ et al, 2006).

Em atuação, o profissional contábil saberá aplicar os princípios éticos, não como uma obrigação, mas como instrumento básico de conduta, qualidade sem a qual sua existência profissional perde o sentido e, contudo, evidenciará seu valor e relevância para a sociedade, em exemplo de profissionalismo e de comportamento ético e moral, porquanto nunca conseguirá ser valorizado, aquele que não se valoriza (SANTOS; ASSIS; ALVES, 2009).

Soares (2000, p.21) afirma que "o profissional cumpre sua função na sociedade se tiver conhecimento técnico - científico, bem como de seus direitos e deveres e executar seu trabalho de acordo com esses conhecimentos, defendendo e valorizando sua profissão".

O desenvolvimento desta pesquisa para o contabilista é valiosa, sendo que visualizou o que pode ser aprimorado em sua conduta ética e o que falta para ser um profissional com as virtudes demandadas pelo mercado e para o cumprimento das funções.

Sendo assim, adotou-se por tema, a percepção dos contabilistas dos escritórios de contabilidade do município de Tangará da Serra em relação à ética e o reconhecimento da classe contábil. Propondo verificar os fatos relevantes na conduta profissional, auxiliando-os no que diz respeito à empregabilidade, a importância deste profissional em comprometimento ético e moral na sociedade e, atingir o objetivo comum a todos profissionais de serem reconhecidos e remunerados no desenvolvimento das atividades.

Ao observar que os contabilistas lidam constantemente com situações no qual estarão a prova ética e moral, que necessitam serem profissionais conhecedores dos diversos campos de atuação para o desempenho de sua função e para o reconhecimento de sua classe, questiona-se: Qual a percepção dos contabilistas dos escritórios de contabilidade do município de Tangará da Serra em relação à ética e o reconhecimento da classe contábil?

Diante do questionamento, o estudo se baseia nas seguintes hipóteses: hipótese 01 na visão dos contabilistas a maioria considera ser profissional ético e, cumpre sempre com as 
Percepção dos contabilistas dos escritórios de contabilidade de Tangará da Serra - MT em relação à ética e o reconhecimento da classe contábil

Elizeu Martins da Silva

Marcelo Evandro Alves

normas estabelecidas pelo Conselho Federal de Contabilidade e, hipótese 02 a maioria acredita no reconhecimento/valorização da classe contábil.

O objetivo geral da pesquisa é verificar a percepção dos contabilistas nos escritórios de contabilidade de Tangará da Serra em relação à ética e o reconhecimento da classe contábil. Para que o objetivo geral seja atendido, pretende-se: verificar juntos aos contabilistas quais virtudes são fundamentais no desenvolvimento das atividades, apurar a percepção dos contabilistas a respeito do reconhecimento da classe contábil em sua categoria e identificar as opiniões dos contabilistas sobre o comportamento ético-legal exercido perante a sociedade.

\section{REFERENCIAL TEÓRICO}

\section{1 Ética x Ética Profissional}

Ética é um ramo da ciência que aborda o significado e o julgamento dos comportamentos dos indivíduos e das organizações, essa avaliação é feita sob a ótica do bem e do mal, do justo ou injusto, do certo ou errado (CALEGARO, 2010). Por conseguinte "ser ético em poucas palavras é ser correto" (MARION; ALMEIDA; VALVERDE, 2002).

"Ética é a ciência do comportamento moral dos homens em sociedade" (NALINI 2001, p.36). A ética como ciência atenta os formatos ideais da atuação humana e procura o fundamento do ser, procurando similitude entre o material e o espiritual. Para Sá (2000, p. 16) a ética "estuda a conduta dos seres humanos, analisando os meios que devem ser empregados para que a referida conduta se reverta sempre em favor do homem. Nesse aspecto o homem torna-se o centro da observação, em consonância com o meio que lhe envolve".

$\mathrm{Na}$ coletividade onde as pessoas buscam atingir objetivos próprios, e são obrigadas a agir diante de situações inesperadas e conflitos existentes na obtenção de agir de forma correta perante a sociedade, a ética é fator singular e ofício por ajustar a humanização, proporcionado uma vida satisfatória.

Para Stukart (2003, p.14), “a ética é uma ciência cujo objetivo é o exame teórico das ações humanas para conseguir uma vida satisfatória e a perfeição integral do homem e é nisso que consiste a felicidade".

A ética profissional é o conjunto de normas de conduta no exercício de suas funções profissionais, ter ética profissional é ser consciente, desempenhar com o dever e com as obrigações de forma livre e correta (SILVA et al, 2004). Fontes e Batista (2005) afirmam que "a ética profissional estuda e regula o relacionamento do profissional com sua clientela, 
Percepção dos contabilistas dos escritórios de contabilidade de Tangará da Serra - MT em relação à ética e o reconhecimento da classe contábil

Elizeu Martins da Silva

Marcelo Evandro Alves

visando a dignidade humana e a construção do bem-estar no contexto sócio - cultural onde exerce sua profissão".

Para Kraemer (2001), compete aos profissionais contábeis regularem seus atos profissionais sob a luz da ética, que conduz operar com integridade, cautela e equilíbrio, visando que suas tarefas sejam realizadas de forma eficaz, competente e com cordialidade, pois do contrário poderá o usuário sofrer sérios resultados inesperados. Além disso, Borges e Medeiros (2007) advertem que com uma falha, um deslize, a imagem do profissional ganha, no mercado de trabalho, a mancha da desconfiança.

Para que amplie com eficácia suas obrigações, várias são as virtudes que um profissional necessita ter, são as cobranças para caracterizar um profissional ético e competente em uma sociedade que encontra em desordem moral. Com tantas indiferenças, onde o assunto da justiça está intensamente ligado tanto à responsabilidade quanto à questão da honestidade (CFC, 2003).

A ética, portanto se encontra pautada nas qualidades, valores do profissional contábil que são adquiridos com a aprendizagem continuada, com boa vontade e esforço (MARION; SANTOS, 2000). Dentre as virtudes indispensáveis ao contabilista destaca-se:

- Sigilo - "Eticamente, o sigilo assume o papel de algo que é confiado e cuja preservação de silêncio é obrigatória” (LOPES DE SÁ, 1996 apud CFC, 2003, p. 26). Para Kraemer (2001) o sigilo nada mais é do que o segredo revelado pelo cliente a um profissional, de forma confidencial, fundamentado no princípio da confiança. Quando o profissional age de forma profissional, com ética e sigilo, alcança a perfeição que se identifica como intenção alcançar a virtude, a qual se deseja para o próximo aquilo que se constitua o melhor (PESSOA, 2006).

- Integridade - demonstra o comportamento do profissional diante de sua classe, clientes e concorrentes, a fim de evitar conflitos de interesses (BORGES; MEDEIROS, 2007).

- Prudência - O conhecimento daquilo que se deve fazer ou evitar, exigindo a noção dos princípios gerais da moralidade e particulares da ação. (CONSELHO FEDERAL DE CONTABILIDADE - CFC, 2003).

- Justiça - É ação de respeitar os direitos e os deveres; é a disposição de oferecer a cada pessoa o que é seu, a igualdade ou a precisão; é o alicerce da vida em coletividade e da participação na essência comum (CFC, 2003).

Neste contexto, o contabilista necessita ter uma consciência profissional que possa conduzir suas tarefas, e virtudes que sirvam de parâmetros para a concretização de tais 
Percepção dos contabilistas dos escritórios de contabilidade de Tangará da Serra - MT em relação à ética e o reconhecimento da classe contábil

Elizeu Martins da Silva

Marcelo Evandro Alves

objetivos, com base na consciência de levar o bem-estar nas nações e na sociedade em geral (CFC, 2003), pois agir de forma ética passa a ser não uma obrigação, mas uma atitude própria do profissional contabilista (CALEGARO, 2010).

Portanto, se espera que o contabilista esteja em constante desenvolvimento, em busca da capacitação da profissão contábil (MARION; SANTOS, 2000). Além disso, Fari e Nogueira (2007) concluem que o contabilista respaldado na ética pode fazer muito mais do que ser apenas contador, o objetivo é de que possa exercer seus trabalhos em qualquer tipo de mercado, sucessivamente atuando-nos diferentes ramos da atividade contábil, "com essa visão, o contabilista deve ser considerado um dos profissionais de maior relevância na sociedade"(FORTES 2005, p. 168).

\subsection{Código de Ética Profissional do Contabilista}

As regras que conduzem a profissão contábil estão descritas no código de ética profissional do contabilista, tornando-se obrigatória o seu cumprimento diante da categoria. Possibilita ainda que os princípios e normas sejam analisados de maneira correta sem ferir ou conter processos antiéticos e incentivando o significado da justiça e dignidade em cada membro da sociedade organizada (BRANCHER; NEU; BOFF, 2010).

O código de ética contábil é um grupo de princípios que relaciona as essenciais práticas de condutas permitidas e proibidas no uso da profissão, sendo empregado aos contabilistas, e não às empresas (PESSOA, 2006). O código de ética além de servir como orientação à ação moral, permite que a profissão contábil afirme seu objetivo de cumprir as regras da coletividade, servindo com lealdade e diligência, respeitando a si mesmo (FIPECAFI, 1997).

Além disso, o código de ética possui diretrizes que amparam os profissionais da contabilidade no dia a dia e assim sustentam uma cadeia de decisões com base no comportamento preestabelecido, ajudando da melhor maneira para as tomadas de decisões (BRANCHER; NEU; BOFF, 2010).

Para que um Código de Ética Profissional seja constituído, é sucinto, que se esboce o seu embasamento filosófico, necessário para formar a construção e materializar o princípio do profissional se conduzir no exercício profissional, de maneira a não prejudicar terceiros e garantir uma qualidade eficaz de trabalho.

O Código de Ética Profissional do Contabilista - (CEPC) surgiu da necessidade da ativação do encadeamento do profissional da Contabilidade com a sociedade e com o próprio 
Percepção dos contabilistas dos escritórios de contabilidade de Tangará da Serra - MT em relação à ética e o reconhecimento da classe contábil

Elizeu Martins da Silva

Marcelo Evandro Alves

grupo profissional determinando ensejo dos conceitos éticos na área da atividade, foi aprovado pela Resolução CFC n ${ }^{\circ} 803 / 96$, e materializou os princípios que foram cristalizados pela tradição, dos hábitos e costumes que foram evoluindo e se aprimorando ao longo dos tempos.

O Código de Ética do Profissional Contábil em seu conteúdo possui cinco capítulos que expõe os objetivos, os deveres e proibições, o valor dos serviços profissionais, o dever com relação aos colegas e a classe, e as penalidades.

O Código de Ética do Profissional Contabilista é uma associação de elementos que cataloga as fundamentais argumentações de comportamentos permitidos e coibidos no exercício da profissão. Conforme Fipecafi (1997, p. 61) o Código de Ética "além de servir como guia à ação moral [...] possibilita que a profissão de contador declare seu propósito de cumprir as regras da sociedade, servir com lealdade e diligência, respeitar a sim mesma".

Quando o profissional contábil atua dentro de uma consciência profissional correta, obedecendo as normas impostas pelo Código de Ética é capaz de ensejar decisões que modificam o destino das pessoas, das empresas, e das instituições, passam a dar-lhes notoriedade, ampliando o grau de satisfação em relação a eles e quase criando uma obrigação de retribuição moral por parte dos beneficiados (SÁ, 2000).

O profissional que presta serviços à sociedade de forma ética recebe de volta o bem social que pratica, criando uma representação que valoriza a si próprio e a classe obtendo o sucesso profissional. Marion (1998, p. 27) afirma que é fator condicionante do sucesso: "ter um comportamento ético-profissional inquestionável, ter conduta pessoal, dignidade e honra; competência e serenidade para que proporcione ao usuário a informação e segurança que ele merece".

\subsection{A importância do profissional contábil na sociedade}

A profissão contábil baseia-se em um "trabalho exercido habitualmente nas células sociais baseadas na explicação dos fenômenos patrimoniais ensejando [...] a tomada de decisões administrativas, além de servir de instrumentação histórica da vida da riqueza" (SÁ, 2000, p. 130).

O objeto da contabilidade é o patrimônio nos seus aspectos qualitativos e quantitativos, em suas variações, diante disso a contabilidade está atrelada em diversas extensões da atividade humana, portanto em todos os campos abrangentes da sociedade existe a necessidade do profissional contábil, seja nas atividades públicas ou privadas. Segundo 
Percepção dos contabilistas dos escritórios de contabilidade de Tangará da Serra - MT em relação à ética e o reconhecimento da classe contábil

Elizeu Martins da Silva

Marcelo Evandro Alves

Fortes (2005, p. 165) "em todas as relações sociais, entre pessoas físicas ou jurídicas, empresas e entidades em geral, nas quais se envolvem fatos suscetíveis de valoração, ai estará presente a contabilidade, sendo os contabilistas os elementos ativos do processo de registro".

As áreas de atuação do contador, segundo Iudícibus e Marion (2000) vão desde a coleta de dados, passando pelo registro dos dados e processamento, que resultam em relatórios que satisfazem a administração, os investidores, os bancos, o governo e outros interessados. O papel do contabilista é suprir com informações precisas cada um dos usuários, na avaliação de suas precisões para alcançar o bem da empresa no interesse das decisões.

O contabilista que se formou em nível superior, como bacharel em Ciências Contábeis denominado contador em sua formação no setor privado tem conhecimento de informações que são artimanha dentro das empresas, podendo atuar como controller, contador de custos, auditor interno, contador fiscal, consultor e cargos administrativos. No setor público a informação do contabilista compreende o orçamento público, pode atuar como contador publico, fiscal de tributos, tribunal de contas e controlador de arrecadações. No ensino pode ser professor, escritor, pesquisador e consultor e como independente poderá exercer a função de auditor independente e perito contábil (MARION, 1998).

Quando o trabalho é prestado pelo contabilista de forma ética e com responsabilidade profissional, promove entusiasmo crucial na sociedade, com segurança e respaldo nas determinações que refletem na vida das pessoas.

\subsection{Contabilidade e a Valorização Profissional}

Sobre valorização da profissão contábil, Marion (1998, p.15) afirma “[...] que a imagem dessa profissão no Brasil ou em países subdesenvolvidos (ou em desenvolvimento) está muito aquém que nos países desenvolvidos".

Isso ocorre pelo fato da contabilidade de várias empresas serem realizada por obrigação legal, pois os empresários não reconhecem a importância que a contabilidade assume para a gestão da empresa, se for elaborada por profissional competente. A desvalorização da profissão contábil também se dá ao fato dos próprios profissionais agindo de forma antiética, praticam atos que vão desde os honorários cobrados com desprestígio para a classe, a concorrência desleal e a falta de qualificação, prejudicando a classe (FARIA, 2009).

"Um profissional bem preparado e bem remunerado, que desempenha suas atividades em um ambiente de trabalho harmônico e condizente com sua importância na sociedade, certamente prestará bons serviços e produzirá bons resultados aos seus clientes e empregadores" (FORTES, 2005, p. 172). 
Percepção dos contabilistas dos escritórios de contabilidade de Tangará da Serra - MT em relação à ética e o reconhecimento da classe contábil

Elizeu Martins da Silva

Marcelo Evandro Alves

Em menção a concorrência profissional, Fortes (2005, p. 178) afirma que "a disputa pelo mercado de prestação de serviços contábeis, assim como nas demais atividades, não pode transformar-se em competição desregrada. O contabilista não deve oferecer ou disputar serviços profissionais mediante aviltamento de honorários ou em concorrência desleal".

O contabilista deve prestar seu concurso moral, intelectual e material. Deste modo, precisa zelar pelo prestígio da classe, bem como a dignidade profissional e o aperfeiçoamento em sua qualificação, atuando sempre com honestidade e dignidade, valorizando assim a profissão contábil (FORTES, 2005).

O contador deve conscientizar-se de que a valorização fundamenta-se, em dois pontos básicos: habilidade técnica e irrepreensível comportamento ético, o qual deve ser inquestionável, o contador deve estar consciente de sua responsabilidade social e profissional e, seriedade em todas as atividades exercidas (CRUZ et al, 2006).

Para a classe contábil é necessário manter elevados padrões éticos junto à sociedade, como condição essencial para a própria sobrevivência. É imprescindível que a classe contábil busque medidas de obter aceitação social que valorizam a credibilidade da profissão junto à sociedade ( ALVES, 2005).

\section{METODOLOGIA}

Para fundamentar metodologicamente o tema abordado será exposto o método científico da pesquisa, a natureza, os meios e todos os procedimentos que serão utilizados para desenvolver o estudo.

Quanto à abordagem do estudo foi de natureza quantitativa e qualitativa. A quantitativa foi utilizada por empregar dados estatísticos. De acordo com Oliveira (2000) o método quantitativo é utilizado no desenvolvimento de pesquisas de âmbito social, econômico, de comunicação, mercadológica, de opinião, representando forma de garantir a precisão dos resultados e evitando distorções de análise e interpretações. Além disso, para Gil (2002) a pesquisa quantitativa busca traduzir em números, opiniões e informações, para classificá-los e analisá-los.

A abordagem qualitativa leva a leituras sobre o assunto da pesquisa, para efeito de apresentação de resenhas, ou seja, relatar minuciosamente o que os diferentes autores ou especialistas escrevem sobre o assunto (OLIVEIRA, 2000). Godoy (1995) ressalva diversidade existente entre os trabalhos qualitativos e enumera um conjunto de características capazes de identificar uma pesquisa desse tipo, a saber: o ambiente natural como fonte direta 
Percepção dos contabilistas dos escritórios de contabilidade de Tangará da Serra - MT em relação à ética e o reconhecimento da classe contábil

Elizeu Martins da Silva

Marcelo Evandro Alves

de dados e o pesquisador como instrumento fundamental; o caráter descritivo; o significado que as pessoas dão as coisas e a sua vida como preocupação do investigador; o enfoque indutivo.

Caracteriza-se também a pesquisa como bibliográfica, pois foi desenvolvida com base em material publicado em livros, revistas, redes eletrônicas, dissertações, teses. A pesquisa bibliográfica é produzida mediante material elaborado, principalmente livros e artigos científicos (GIL, 1999).

Quanto aos meios foi elaborada pesquisa de campo, e para alcançar embasamento foi elaborado questionário misto com 15 perguntas objetivas de múltipla escolha, 01 pergunta aberta e aplicado junto aos contabilistas que atuam em escritórios. A pesquisa foi realizada no mês de março do ano de 2012.

A coleta de dados foi realizada por meio de questionário desenvolvido a partir do referencial teórico desta pesquisa, o questionário foi entregue pessoalmente para cada integrante da amostra. O questionário constituiu em duas partes: perguntas de caráter censuário, para definir o perfil dos respondentes, e perguntas relacionadas à percepção ética e a maneira como os contabilistas enxergam o reconhecimento/valorização da classe contábil em Tangará da Serra - MT.

De acordo com o Conselho Regional de Contabilidade de Mato Grosso ( CRC-MT, 2011) atualmente soma-se no Mato Grosso um total de 6.842 profissionais ativos, desses profissionais 237 estão alocados em Tangará da Serra. Em se tratando escritório de contabilidade temos entre individual e sociedade um total de 49 constituídos e ativos em Tangará da Serra. Perante a Prefeitura Municipal conforme Cnae específico obteve-se uma relação de 33 escritórios registrados no setor de Alvará Municipal.

Diante do universo de 49 escritórios cadastrados no CRC-MT, obteve-se uma amostra de 34 escritórios localizados, com a distribuição de 01 questionário por escritório respondido por contador ou técnico em contabilidade com registro no Conselho Regional de Contabilidade de Mato Grosso. A amostra obtida de 34 questionários frente ao total universo da pesquisa corresponde a $69,38 \%$.

\section{RESULTADOS E DISCUSSÃO}

Nesta parte será abordada a demonstração e as interpretações relacionadas aos dados obtidos através da pesquisa, realizada junto aos entrevistados. As informações foram expostas mediante gráficos com tópicos e seus respectivos percentuais. 
Percepção dos contabilistas dos escritórios de contabilidade de Tangará da Serra - MT em relação à ética e o reconhecimento da classe contábil

Elizeu Martins da Silva

Marcelo Evandro Alves

Gráfico 01: Percentual de entrevistados por sexo, em Tangará da Serra, em 2012.

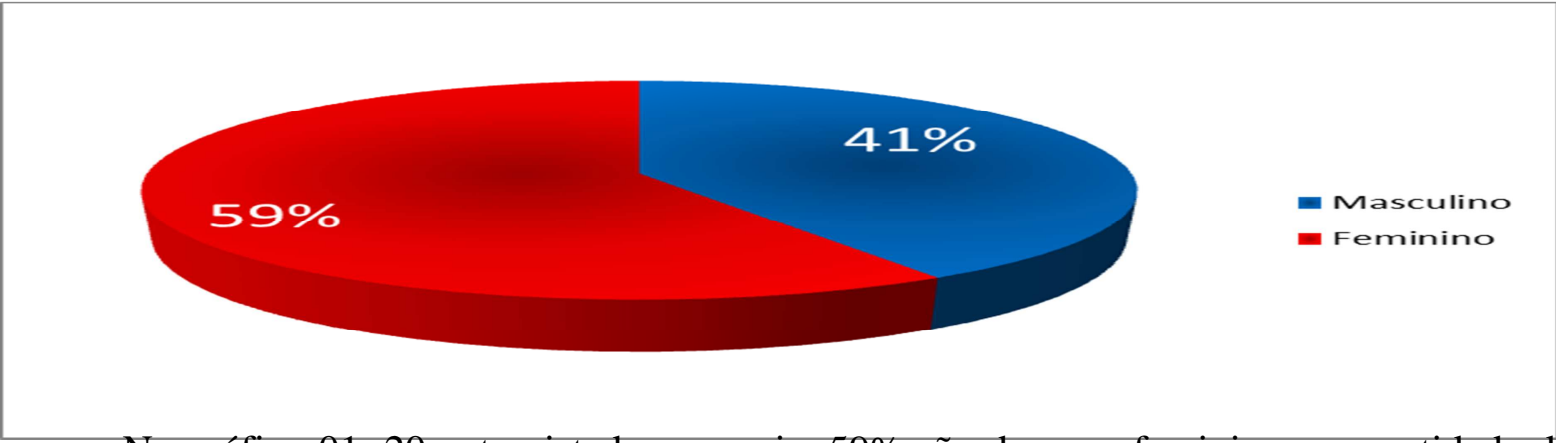

No gráfico 01, 20 entrevistados, ou seja, 59\% são do sexo feminino, a quantidade de pessoas do sexo masculino é apenas $18 \%$ menor. Expressa que o mercado contábil no universo da pesquisa encontra-se aproximadamente equilibrado neste quesito, mostrando que tanto os homens quanto as mulheres possuem capacidade para exercer a profissão na área contábil no município de Tangará da Serra, e as respostas dos entrevistados são de essencial seriedade para este estudo. Para Coser (2005) a participação da mulher no mercado de trabalho vem acontecendo de maneira crescente nos diversos campos de atuação. Na área contábil, as mulheres ocupam índices de participação cada vez mais expressivos.

Gráfico 02: Percentual de entrevistados por idade, em Tangará da Serra, em 2012.

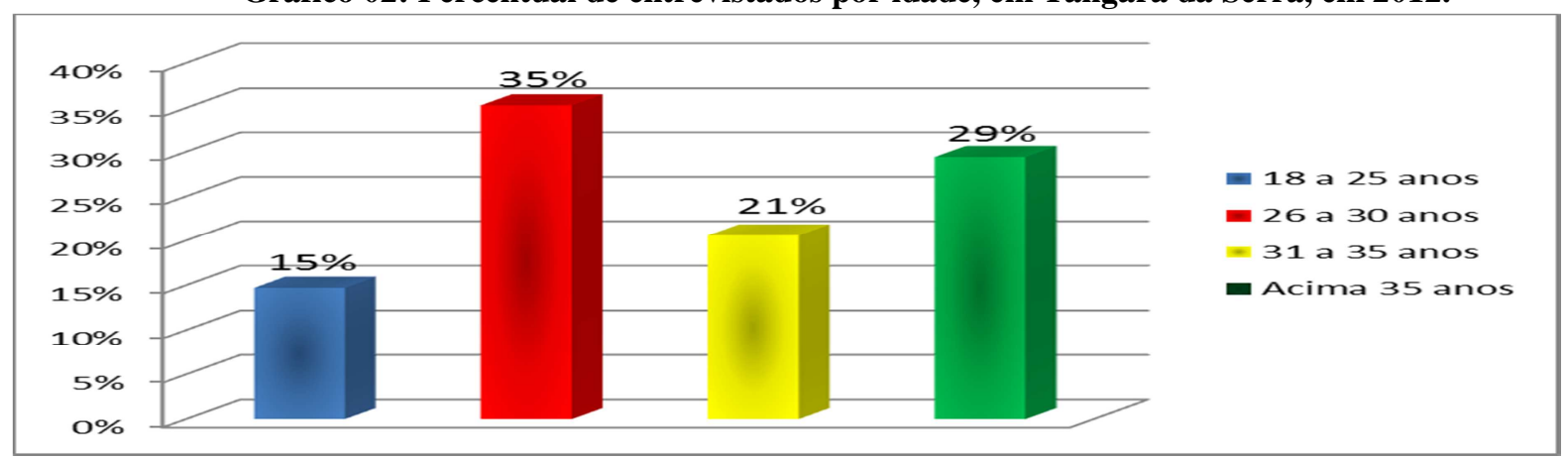

Segundo o gráfico 02 em relação à faixa etária, caracteriza-se por amostra com variações relevantes, do total pesquisado 12 entrevistados, representados por $35 \%$, possui de 26 a 30 anos. Ainda na pesquisa há 5 entrevistados, ou seja, 15\% com idade entre 18 a 25 anos, pessoas novas que tiveram contato recentemente com a ciência contábil, e 10 entrevistados $(29 \%)$ com idade acima de 35 anos.

Gráfico 03: Percentual de entrevistados, por tempo de profissão, em Tangará da Serra, em 2012.

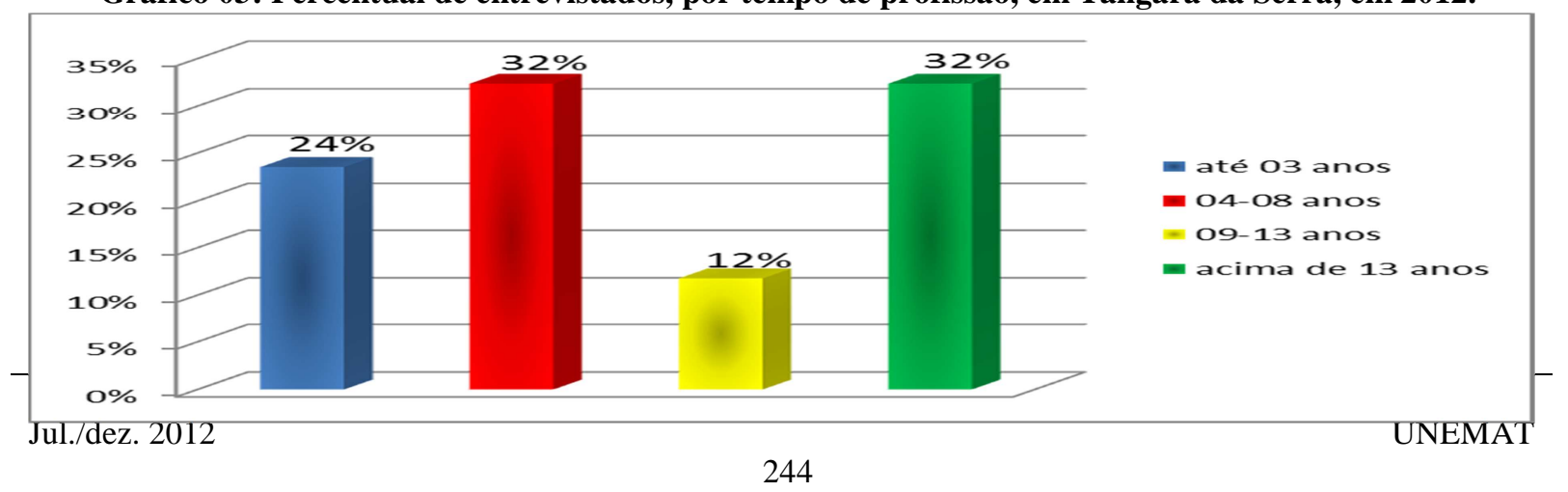


Percepção dos contabilistas dos escritórios de contabilidade de Tangará da Serra - MT em relação à ética e o reconhecimento da classe contábil

Observa-se no gráfico 03 que os contabilistas com 04 a 08 anos de profissão contábil, representam um percentual de 32\% (11 entrevistados) da amostra que já atuam no mercado de trabalho, também com 32\% (11 entrevistados) destacam-se os profissionais que possui experiência na área, pois já estão acima de 13 anos na profissão. Vale ressaltar que 24\% (8 entrevistados) possuem até 03 anos de profissão são os que saem das universidades com entusiasmo e pretensão de ingressar no mercado de trabalho, e podem desta forma contribuir na profissão contábil.

Gráfico 04: Percentual de entrevistados, por registro no CRC, em Tangará da Serra, em 2012.

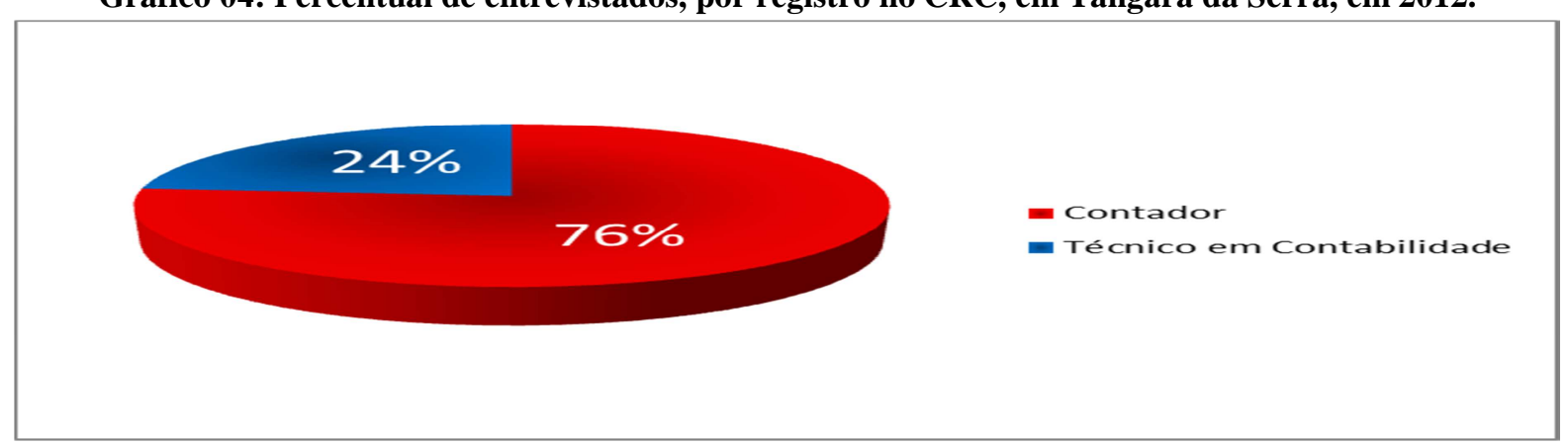

No gráfico 04 foi questionado se o registro do profissional era de Contador ou Técnico em Contabilidade, 26 entrevistados (76\%) responderam que são bacharéis em contabilidade e tem o seu registro no CRC de contador, 8 entrevistados (24\%) declaram ter seu registro de técnico em contabilidade.

Gráfico 05: Percentual de entrevistados, por setor de atuação, em Tangará da Serra, em 2012.

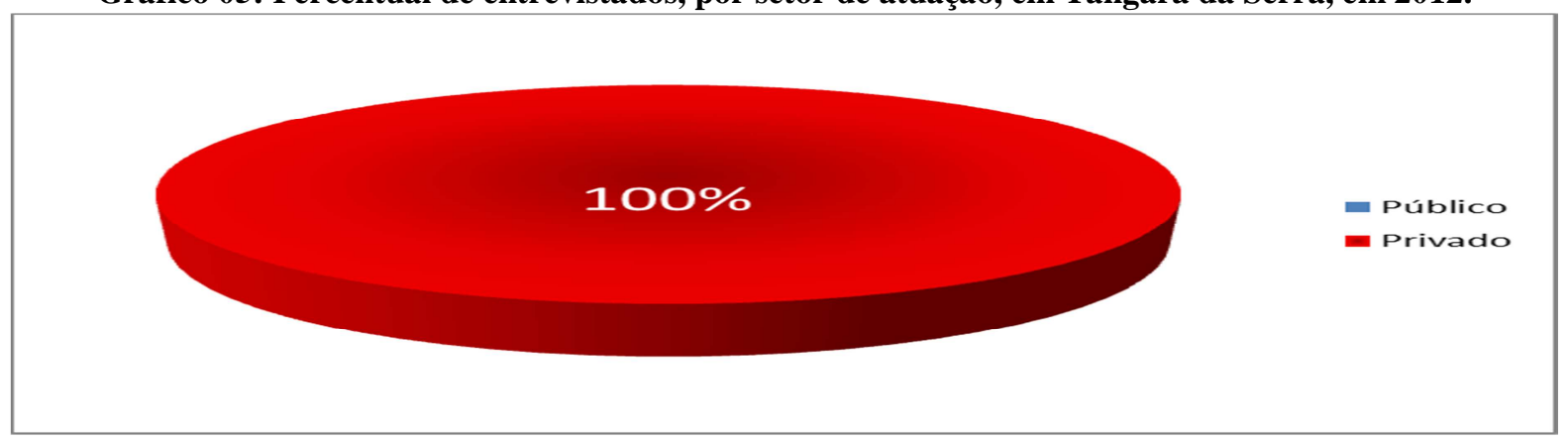

Conforme o gráfico 05 , ao ser questionado em que setor de trabalho o profissional atua, dos entrevistados $100 \%$ respondam que é no setor privado, aqui inclui os escritórios de contabilidade como objetivo proposto na pesquisa. Rodrigues (2009) afirma que está em ascensão cada vez mais a necessidade de se ter um contador nas empresas como influência das tomadas de decisões.

Gráfico 06: Percentual de entrevistados, que leem ou utilizam o Código de Ética, em Tangará da Serra, em 2012. 
Observa-se no gráfico 06 que dos entrevistados pesquisados 27, ou seja, $79 \%$ declaram que o código de ética profissional do contabilista é lido ou utilizado no desempenho das funções, e 7, ou seja, $21 \%$ não utilizam o código na execução do seu trabalho, destes 5 são contadores e 2 técnicos em contabilidade. O profissional contábil ao confirmar suas ocupações profissionais, assume prontamente responsabilidades éticas e legais que são descritas pelo Código de Ética do Profissional ( RODRIGUES, 2009), por conseguinte, o código de ética do contabilista, visa ajudar nas ações dos profissionais na execução de sua função e viabilizar o convívio entre os contabilistas ( CÂNDIDO, 2009).

Gráfico 07: Percentual de entrevistados, sobre a opinião do código de ética do contabilista, em Tangará da Serra, em 2012.

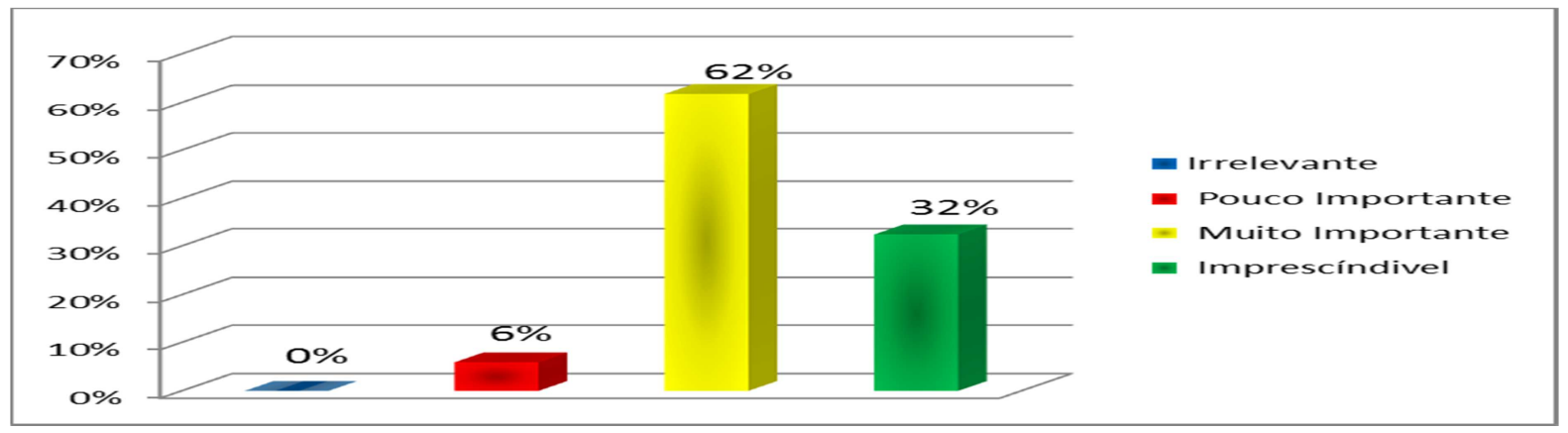

No gráfico 07 , o código de ética em relação à boa conduta no exercício das rotinas profissionais foi considerado por 32 entrevistados (94\%) como muito importante e imprescindível; e 2 entrevistados (6\%) compostos por um contador e um técnico em contabilidade acham o código de ética pouco importante. “ O Código de Ética possui parâmetros que auxiliam os profissionais da contabilidade no dia a dia e assim sustentam uma série de decisões baseadas em uma conduta preestabelecida, auxiliando da melhor forma para as tomadas de decisões ( BRANCHER, 2010, p.33).”

Gráfico 08: Percentual de entrevistados, que se declaram serem profissionais éticos ou não, em Tangará da Serra, em 2012.

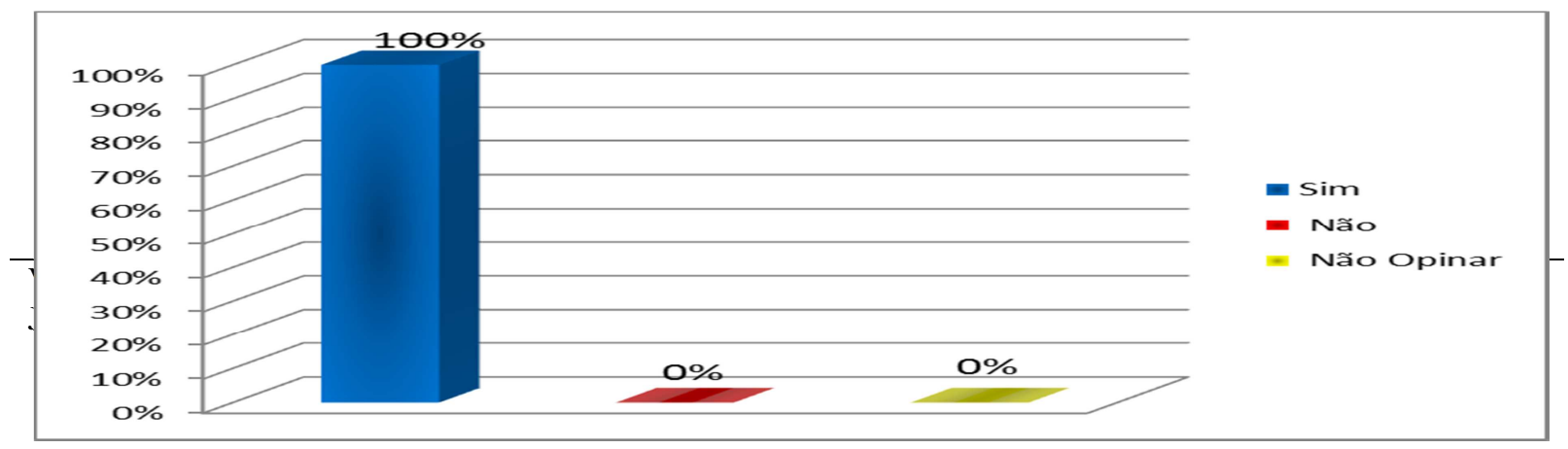


Assim como evidenciado no gráfico 08 os contabilistas entrevistados, no percentual de $100 \%$, se consideram éticos no desempenho profissional. Para Siqueira ( 2005) todo aquele que segue o código de ética da profissão é considerado ético, competente, de confiança, ou seja, é estimado um profissional de bom caráter. Afirma ainda que:

“ A responsabilidade dos contabilistas e sua importância num contexto social só tende a crescer, pois a procura das empresas por profissionais competentes na área é grande, e aquele que não estiver bem preparado e não tiver uma conduta ética profissional exemplar, pode se considerar fora do mercado ( SIQUEIRA, 2005, p. 76)".

Gráfico 09: Percentual de entrevistados, em relação ao cumprimento das normas do Conselho, em Tangará da Serra, em 2012.

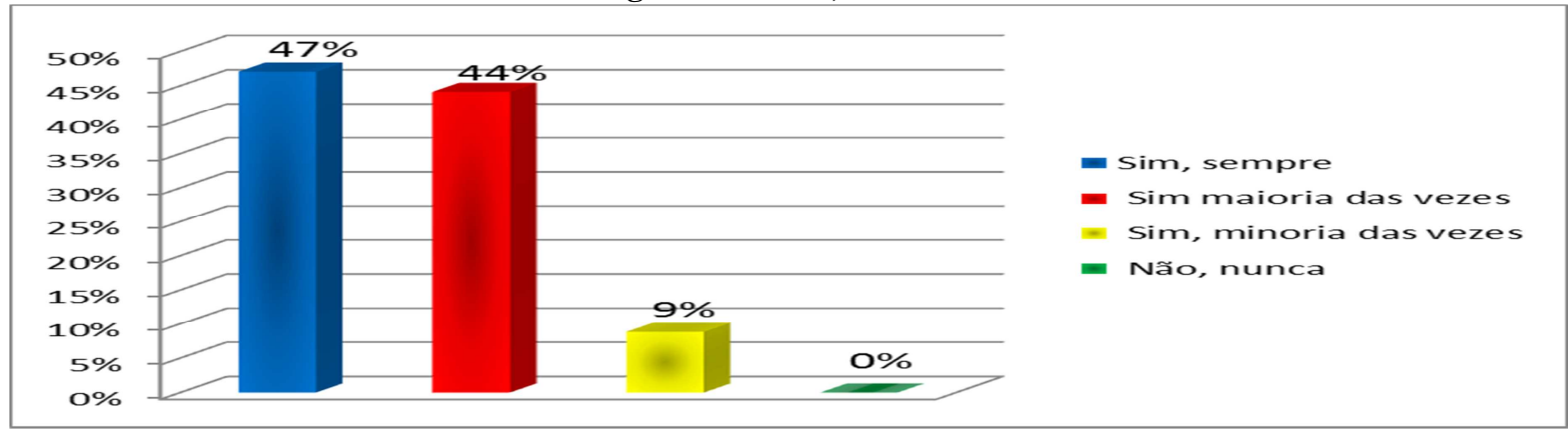

Verifica-se no gráfico 09 que ao ser perguntado aos contabilistas se cumprem todas as normas elaboradas pelo Conselho Federal de Contabilidade, mesmo que discorde de algumas ou de todas, um total de 16 entrevistados (47\%) afirmaram que sim, sempre. Ainda dos entrevistados 15 (44\%) responderam que cumprem as normas, mas em sua maioria. E o que chamou atenção foi 3 contadores que representam $9 \%$ da pesquisa, responderam que as normas do Conselho são cumpridas, mas em sua minoria.

Os profissionais contábeis devem exercem suas atividades de acordo com as normas do Conselho Federal de Contabilidade e dos Conselhos Regionais, onde, é cabível aplicar penalidades para o profissional que não cumprir com as exigências impostas (SANTOS; ASSIS; ALVES, 2009).

Gráfico 10: Percentual por opinião de entrevistados, em relação às virtudes essenciais para o desempenho profissional ético, em Tangará da Serra, em 2012.

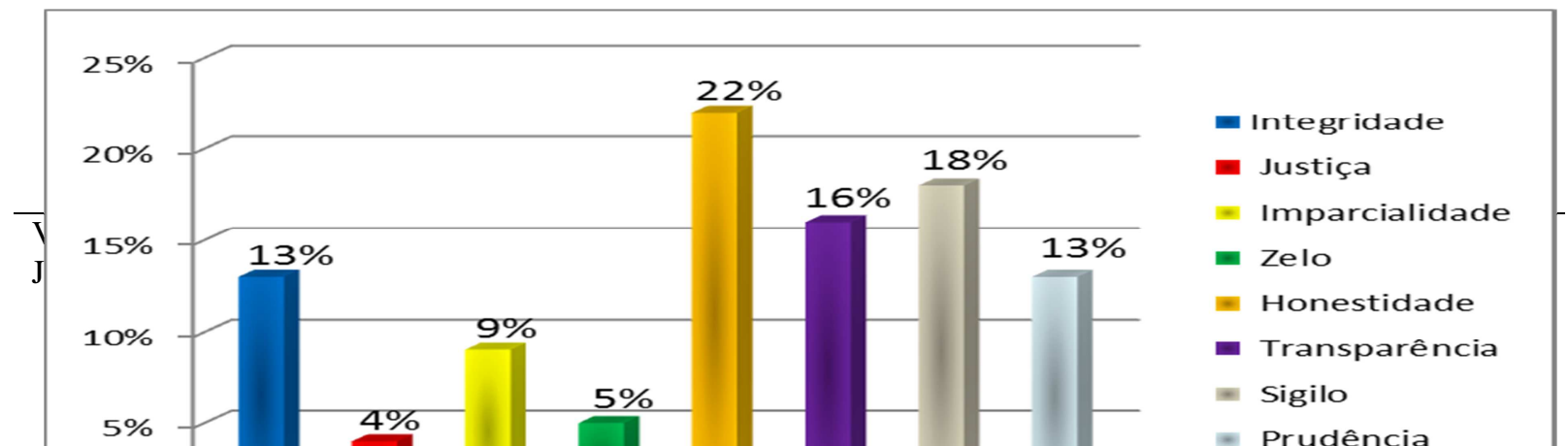


No gráfico 10 ao verificar as virtudes que o contabilista consideram fundamental no desempenho profissional ético, apresentou destaque como mais importante à honestidade, seguido de sigilo, transparência, prudência, integridade, imparcialidade, zelo e justiça. $\mathrm{Na}$ questão estão relacionadas várias virtudes do profissional contábil, que são consideradas importantes para os profissionais da área contábil, todas receberam votos, mas, a primeira virtude considerada a mais importante foi à honestidade com $22 \%$. A honestidade está relacionada com a confiança que se é depositada, com responsabilidades diante do bem de terceiros e a sustentação de seus direitos. São atitudes que não aceita meio termo, relatividade ou tolerância, pois a maior incumbência do profissional contábil é exercer suas atividades com honestidade, independência e sinceridade, com base nos princípios fundamentais de contabilidade, nas normas Brasileiras de contabilidade e no código de ética da profissão ( CFC, 2003).

A segunda virtude mais votada foi o sigilo com 18\%, para Kraemer (2001) o sigilo nada mais é do que o segredo revelado pelo cliente a um profissional, de forma confidencial, fundamentado no princípio da confiança. Quando o profissional age de forma profissional, com ética e sigilo, alcança a perfeição que se identifica como intenção alcançar a virtude, a qual se deseja para o próximo aquilo que se constitua o melhor (PESSOA, 2006). Por isso, o ideal é que se preserve em sigilo tudo o que se conhece do cliente no exercício da profissão (CFC, 2003).

A terceira virtude que os contabilistas consideram fundamental para o cumprimento do dever ético é a transparência com $16 \%$.

\begin{abstract}
Observa-se que no mercado profissional de contabilidade, a transparência nas informações, torna-se um dos princípios básicos para que o contador seja reconhecido, dentro de uma visão mais moderna da contabilidade. Tornando-se vital para o profissional de contabilidade exercitar continuamente a ética em sua atividade, pois é relevante a clareza, objetividade, idoneidade e imparcialidade, isto para que o usuário tenha confiança no produto final dos contabilistas, que é representado pela informação contábil e posteriormente traduzido em relatórios contábeis ( BOONI; LAVANHOLE; SILVA, 2009, p.35).
\end{abstract}

Vale ressaltar que as virtudes integridade e prudência obtiveram 13\% dos votos, acompanhado de imparcialidade com $9 \%$, zelo com $5 \%$ e por ultimo a justiça com $4 \%$. 
Gráfico 11: Percentual por opinião de entrevistados, em relação aos motivos de escolha da profissão, em Tangará da Serra, em 2012.

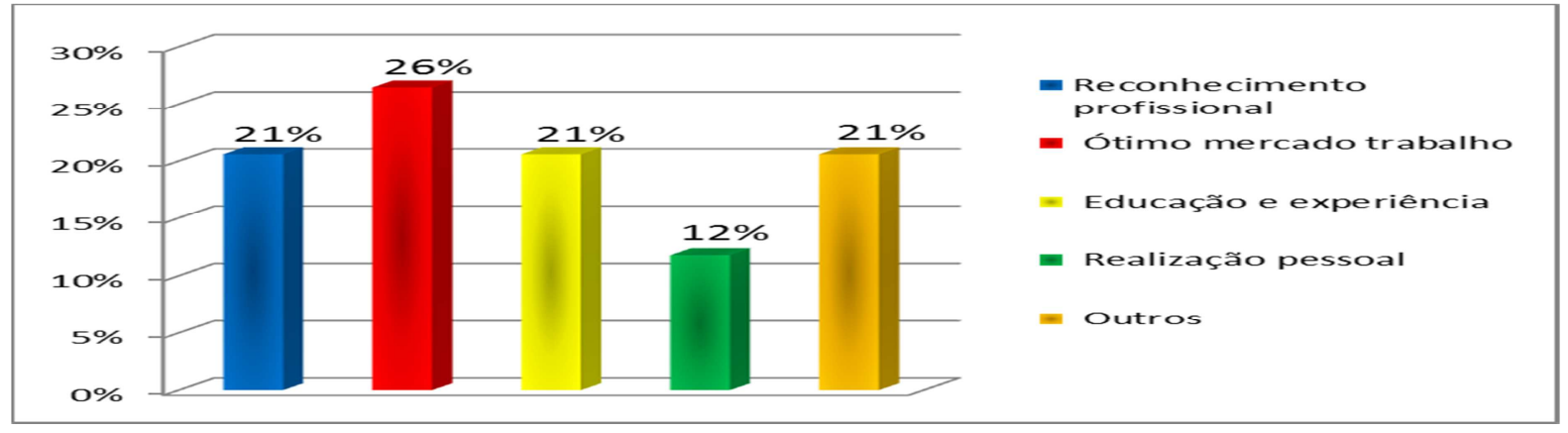

Conforme o gráfico 11 foi questionado quanto ao motivo que levou a escolha da profissão contábil, 9 entrevistados (26\%) responderam que é pelo ótimo mercado de trabalho. Andrade e Muylder (2010) afirmam que diante dos mercados competitivos as empresas passaram a estimar uma solução primordial à sua sobrevivência: a contabilidade, uma ciência social que tem a capacidade de fornecer aos usuários informações favoráveis e necessárias ao procedimento de tomada de decisões. O reconhecimento profissional, e a educação e experiência alcançou 7 votos (21\%). E a opção outros, respondido por 7 contabilistas, obteve $21 \%$ dos votos. Um entrevistado afirma que o motivo que levou a escolha da profissão foi "já trabalhava na área", outro entrevistado confirma ser devido ao "retorno financeiro" e ainda um terceiro entrevistado relata que o motivo foi "na época era a opção disponível". E dos entrevistados $12 \%$ responderam que foi pela realização pessoal.

Gráfico 12: Percentual por opinião de entrevistados, em relação ao grau de satisfação da remuneração, em Tangará da Serra, em 2012.

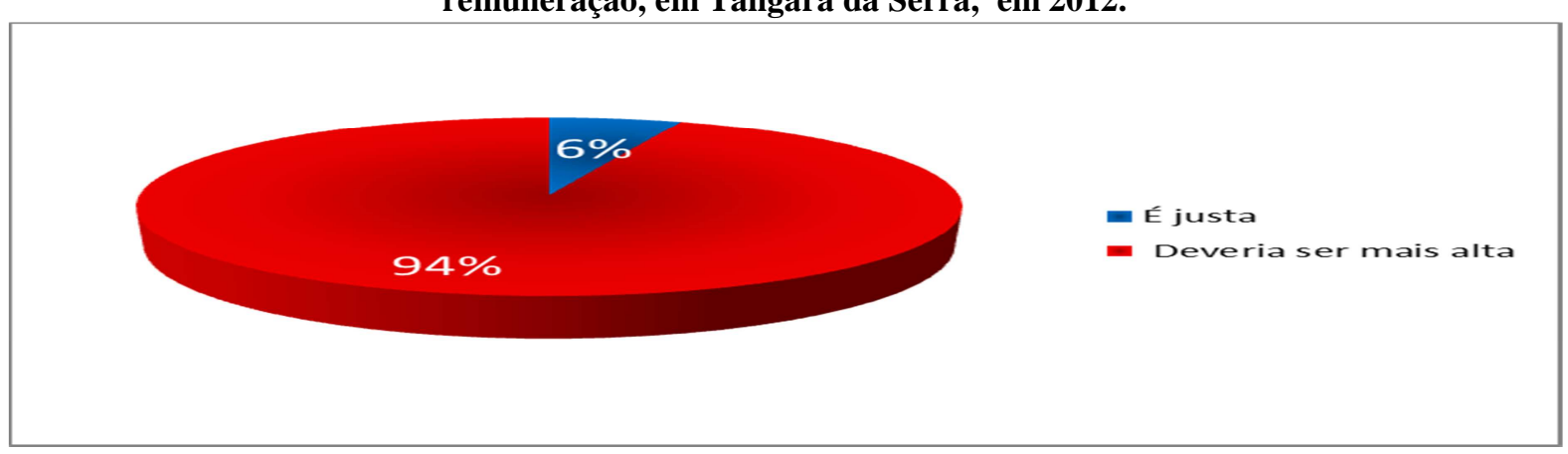


Percepção dos contabilistas dos escritórios de contabilidade de Tangará da Serra - MT em relação à ética e o reconhecimento da classe contábil

Elizeu Martins da Silva

Marcelo Evandro Alves

Verifica-se no gráfico 12 que 32 entrevistados (94\%) consideram que sua remuneração deveria ser mais alta. Para Valgas (2005) é a qualificação e a ética profissional que vão garantir aos contabilistas uma remuneração digna.

E 2 entrevistados (6\%) representados por contadores consideram justa a satisfação de sua remuneração.

Gráfico 13: Percentual por opinião de entrevistados, em relação à estabilidade e segurança financeira quanto à remuneração, em Tangará da Serra, em 2012.

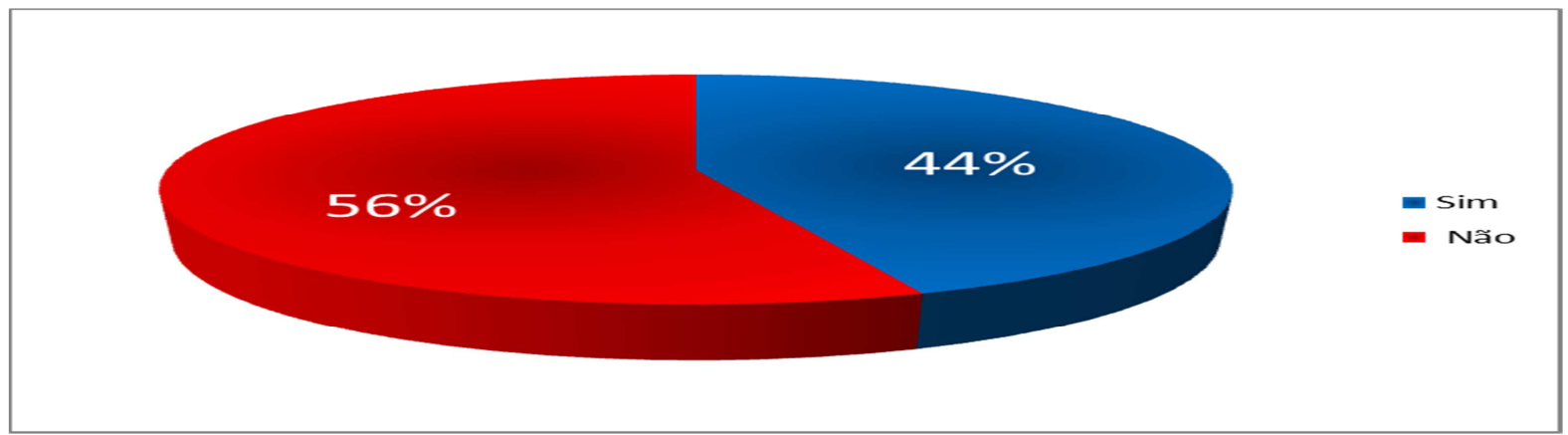

Observa-se no gráfico 13 que 44\% dos entrevistados consideram ter estabilidade e segurança financeira perante sua remuneração, 13 entrevistados afirmaram que a remuneração deveria ser mais alta na resposta anterior, e afirmam nesta pergunta que o montante de sua remuneração é o suficiente para trazer a estabilidade e segurança financeira necessária. $\mathrm{O}$ restante 19 entrevistados (56\%) consideram que sua remuneração não é satisfatória para acreditar na estabilidade e segurança financeira.

Gráfico 14: Percentual por opinião de entrevistados, em relação ao acréscimo da remuneração, em Tangará da Serra, em 2012.

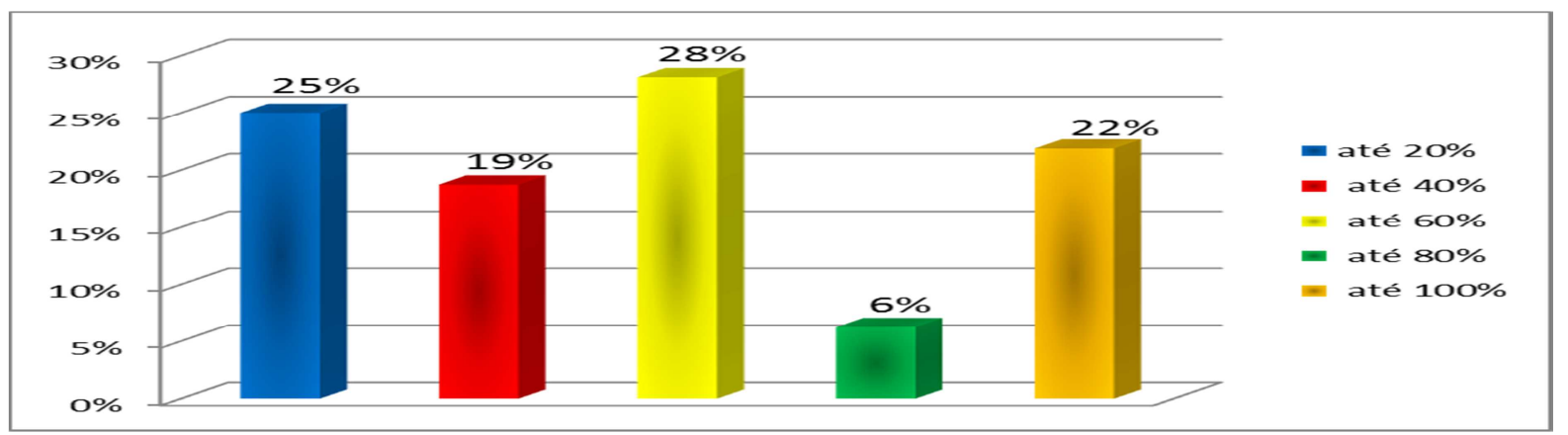

No gráfico 14 foi questionado aos entrevistados qual o percentual de aumento salarial poderá ser acrescido na remuneração em virtude de qualificação (especialização, mestrado/doutorado) e/ou a experiência desenvolvida na área contábil, no qual $28 \%$ dos 
Percepção dos contabilistas dos escritórios de contabilidade de Tangará da Serra - MT em relação à ética e o reconhecimento da classe contábil

Elizeu Martins da Silva

Marcelo Evandro Alves

entrevistados responderam que até $60 \%, 25 \%$ afirmam que até $20 \%$. A terceira maior resposta com $22 \%$ confirmam que sua remuneração pode ser acrescida até $100 \%$.

O perfil do contador moderno é o de um homem de valor que precisa acumular muitos conhecimentos, mas que tem um mercado de trabalho garantido, todavia, que o profissional tenha consciência de que a maior remuneração exige qualidade de trabalho e que esta se consegue com o melhor conhecimento, com estudo, com aplicação, esses profissionais tem que ser tecnicamente inteligentes e ter capacidade criativa, ser proativo, ter alta integridade, não podem ter medo de arriscar, não podem ser egoístas, ter boa capacidade de comunicação, compreender a sistemática econômico-financeira, política e social, em nível local, regional ou mesmo internacional, entender dos aspectos técnicos dos negócios, para isso tem que estar sempre atualizado e procurar estudar a situação da empresa a qual irá prestar assessoria ou consultoria, sem essas concepções e consciência, o desenvolvimento profissional fica bastante prejudicado ( MOURA; FONSECA; DIAS; 2003, p. 7).

Vale ressaltar que dos entrevistados que responderam, 19\% consideram um aumento de até $40 \%$ em sua remuneração, e $6 \%$ representados por dois contadores poderá ser acrescida até $80 \%$ sua remuneração.

Gráfico 15: Percentual por opinião de entrevistados, em relação ao reconhecimento/valorização da classe contábil, em Tangará da Serra, em 2012.

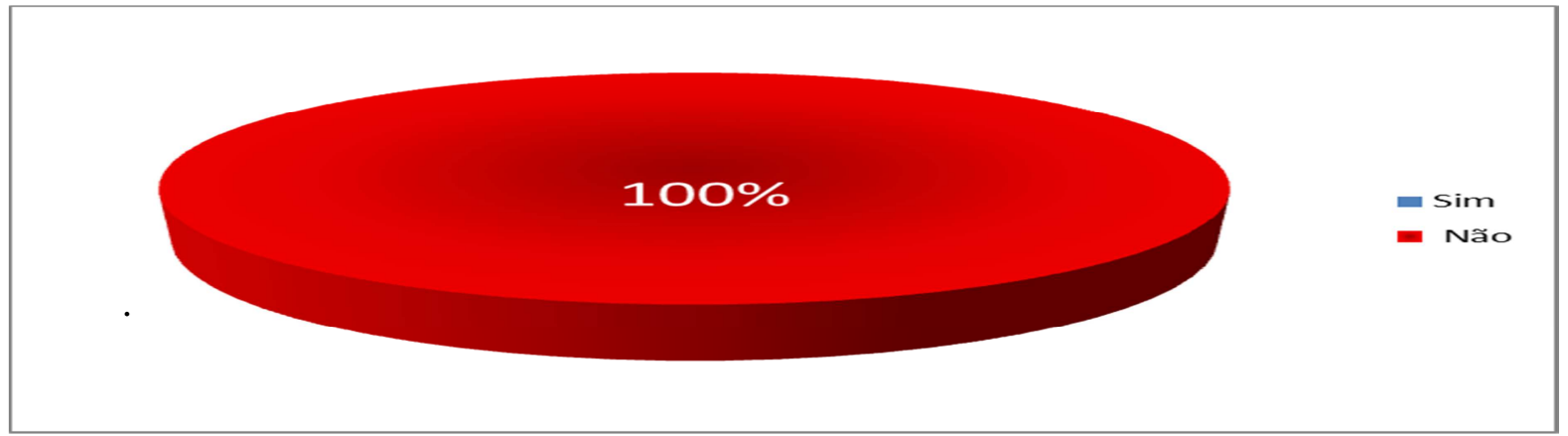

Verifica-se que no gráfico 15 que os 34 entrevistados (100\%) não consideram a classe contábil reconhecida/valorizada.

$\mathrm{Na}$ pergunta 16, caso o entrevistado respondesse que a classe contábil não é reconhecida na resposta da pergunta 15, foi então orientado destacar os pontos fundamentais para que tanto a profissão e a classe contábil tenha o devido reconhecimento/valorização no cenário atual.

O entrevistado 1 afirma que " grande parte dos empregados vê a classe contábil como uma ferramenta para atender apenas as exigências do fisco, o que no meu ver deveria ser vista como uma ferramenta gerencial, auxiliando assim nas tomadas de decisões e investimentos, hoje em dia só as grandes empresas tem essa concepção, enquanto não mudar essa mentalidade a classe nunca será valorizada". 
Percepção dos contabilistas dos escritórios de contabilidade de Tangará da Serra - MT em relação à ética e o reconhecimento da classe contábil

Elizeu Martins da Silva

Marcelo Evandro Alves

O entrevistado 5 chama a atenção para que haja união entre os contabilistas, e alerta para se cobrar o preço justo pelos serviços prestados, “o principal problema é a remuneração baixa e a falta de união da classe" afirma o entrevistado 8 .

Para o entrevistado 12 deve-se " estabelecer padrão ou uma tabela de preços, sindicato da classe no município, pois não tem”. Segundo o entrevistado 19 é preciso “ melhorar o nível de conhecimento de todos os profissionais envolvidos, inclusive com a aplicação do código de ética para aqueles profissionais que disputam serviços no estilo da era medieval".

Observa-se que o entrevistado 20 chama a vigilância do Conselho de Contabilidade: "deveria atuar com mais rigor, na aplicação de cursos de qualificação e educação continuada".

E com pesar o entrevistado 32 relata que: “ em primeiro lugar o problema nasceu por parte dos próprios profissionais, que deixaram que medidas politicas de apuração de imposto lhes deixassem acomodados, assim eles passaram a serem meros despachantes fiscais, e agora é o momento de resgatar o tempo perdido. Vejo com muita tristeza que existem certos profissionais que novamente estão querendo atribuir responsabilidades para outras áreas e quando se derem conta o espaço vai estar ocupado pela área da tecnologia ou outros profissionais - a hora é agora, vamos acordar"!

\section{CONCLUSÃO}

O estudo realizado permitiu visualizar diante dos resultados obtidos com a pesquisa, a percepção dos contabilistas que atuam nos escritórios de contabilidade em Tangará da Serra MT em relação à ética e o reconhecimento da classe contábil. A hipótese 01 foi validada parcialmente, pois a maioria dos contabilistas entrevistados considera ser um profissional ético conforme gráfico 08, e, 53\% dos entrevistados conforme gráfico 09 cumprem as normas estabelecidas pelo Conselho na maioria e na minoria das vezes. A hipótese 02 , portanto foi refutada devido às opiniões dos contabilistas considerarem a classe contábil desvalorizada, de acordo com o gráfico 15 .

O objetivo geral do estudo foi alcançado, sendo que foi possível verificar a percepção dos contabilistas do ponto de vista ético e o devido reconhecimento da classe. Os objetivos específicos foram atingidos por que foi possível conhecer as virtudes apontadas pelos contabilistas como sendo fundamentais para o desenvolvimento das atividades éticas, também foi possível apurar através do questionário qual a percepção dos contabilistas no que diz respeito ao reconhecimento/valorização da classe contábil e identificar as opiniões dos contabilistas sobre o comportamento ético-legal exercido perante a sociedade. 
Percepção dos contabilistas dos escritórios de contabilidade de Tangará da Serra - MT em relação à ética e o reconhecimento da classe contábil

Elizeu Martins da Silva

Marcelo Evandro Alves

Diante do divulgado no decorrer do estudo formado, acredita-se estar claro que a classe contábil perante os contabilistas que atuam nos escritórios de contabilidade de Tangará da Serra - MT é desvalorizada. Os autores utilizados tiveram suas idéias e pensamentos considerados e cogitados na prática da pesquisa.

Pode-se concluir também que a sociedade está em constante mudança, portanto é necessário o contabilista realizar seu trabalho de maneira ética, séria e com responsabilidade, voltado sempre ao pronto atendimento das necessidades dos clientes. E que aja educação continuada para o profissional se qualificar, buscando sempre programas de mudança, de maneira inovadora, que tragam benefícios para o seu ramo de atividade.

É importante ressaltar como descrito pelos contabilistas que deve haver mais união entre os profissionais da área em ordem municipal a fim de combater profissionais que denigrem a imagem da profissão levando ao descrédito o mercado consumidor em relação à mão-de-obra contábil. Igualmente, vale alertar que é de fundamental importância o contabilista cumprir as normas do Conselho Federal para uma boa conduta perante os companheiros de classe, tendo como objetivo a consciência de sua função.

Outro aspecto importante verificado na pesquisa em relação ao reconhecimento/valorização da classe contábil, conforme gráfico 14 foi que, 18 entrevistados, ou seja, $56 \%$ (cinquenta e seis por cento), responderam que poderá ser acrescido um percentual de $60 \%$ até $100 \%$ nas respectivas remunerações, através da qualificação (Especialização, Mestrado/Doutorado). Portanto, como sugestão ao contabilista para a sua valorização financeira, o caminho a seguir é a atualização profissional, não apenas buscando as novidades de sua atividade, mas sim conhecimentos que também influenciam na sua profissão como, por exemplo, a política, a economia e outras áreas afins.

Para os pesquisadores, o que se pode dizer é que este trabalho teve o objetivo de mostrar a percepção dos contabilistas dos escritórios de contabilidade, perante a ética e ao reconhecimento da classe contábil, e abrir o leque de discussões que todo o tema pode abranger podendo ser este a base para trabalhos mais amplos perante maior número de entrevistados e aprofundamento sobre o tema em questão pesquisado.

\section{REFERÊNCIAS}

ALVES, Francisco José dos Santos. Adesão do contabilista ao Código de ética da sua profissão: um estudo empírico sobre percepções. Disponível em: <http://www.teses.usp.br/teses/disponiveis/12/12136/tde-23012006-103126/pt-br.php> Acesso em: 07/04/2012. 
Percepção dos contabilistas dos escritórios de contabilidade de Tangará da Serra - MT em relação à ética e o reconhecimento da classe contábil

Elizeu Martins da Silva

Marcelo Evandro Alves

ANDRADE, Jacqueline Aparecida Batista de, MUYLDER, Cristiana Fernandes de. A relevância dos temas inovação e qualidade na pesquisa contábil: um estudo bibliométrico em eventos científicos no Brasil. ABCustos Associação Brasileira de Custos. Vol. V n.3 set/dez 2010.

BORGES, Erivan, MEDEIROS, Carlos. Comprometimento e ética profissional: Um estudo de suas relações junto aos contabilistas. Revista Contabilidade e Finanças, USP. São Paulo, n. 44, p. 60-71, Maio/Agosto 2007.

BORGES, Erivan, MEDEIROS, Carlos. Preceitos e Regras Éticas: como se dá a introjeção de preceitos éticos por contadores e técnicos em contabilidade na sua atuação profissional. Contabilidade Vista \& Revista, Belo Horizonte, v.18, n. 2, p. 49-72, Abril / Junho 2007.

BRANCHER, Cristiane, NEU, Márcia Adriana, BOFF, Marines Lucia. Ética profissional: entendimento dos acadêmicos de Ciências Contábeis da Unoesc, Unoesc \& Ciência - ACSA, Joaçaba, v.1, n.1, p. 31-38, jan./jun. 2010.

BOONI, Diego, LAVANHOLE, Laércio, SILVA, Luciana Dias da. A evolução da contabilidade e a valorização do profissional contábil. Disponível em: $<$ http://pt.scribd.com/doc/52422495/A-EVOLUCAO-DA-CONTABILIDADE-E-AVALORIZACAO-DO-PROFISSIONAL> Acesso em: 07/04/2012.

CALEGARO, Jéferson Marques. Profissionais da Contabilidade: Infrações éticas cometidas, punições aplicadas e percepções acerca da importância do ensino de disciplina sobre ética e legislação profissional. Disponível em:

〈http://www.lume.ufrgs.br/bitstream/handle/10183/25728/000751597.pdf?sequence=1 > Acesso em: 21/08/2011.

CÂNDIDO, Norma Faria. Ética profissional do contabilista: um meio de valorização do profissional contábil. Disponível em:

〈http://www.biblioteca.ajes.edu.br/arquivos/monografia_20110913204007.pdf>

Acesso em: 07/04/2012.

CECCONELLO, Antônio Renato, BARBOSA, Claudionor Francisco, CÉLICE, Eduardo de Souza; KOUNROUZAN, Marcia Covaciric, DI GIORGI, Wanny Arantes Bongio Vanni.

Métodos e técnicas de pesquisa em contabilidade - São Paulo: Saraiva 2003.

CONSELHO FEDERAL DE CONTABILIDADE. Abordagens éticas para o

Profissional contábil. Brasília: CFC, 2003.

CONSELHO REGIONAL DE CONTABILIDADE DE MATO GROSSO - CRC/MT, 2011.

Disponível em: 〈http://www.crcmt.org.br/site/novo/index.php?act=o_crc $>$

Acesso em 05/10/2011

CONSELHO REGIONAL DE CONTABILIDADE DE MATO GROSSO - CRC/MT, 2011.

Quantos somos. Disponível em:

<http://www.crcmt.org.br/site/novo/registro_quantos_1.php>

Acesso em 23/03/2012

CONSELHO REGIONAL DE CONTABILIDADE DE MATO GROSSO - CRC/MT, 2011.

Quantos somos. Disponível em:

<http://www.crcmt.org.br/site/novo/registro_quantos_2.php>

Acesso em 23/03/2012 
Percepção dos contabilistas dos escritórios de contabilidade de Tangará da Serra - MT em relação à ética e o reconhecimento da classe contábil

Elizeu Martins da Silva

Marcelo Evandro Alves

CONSELHO REGIONAL DE CONTABILIDADE DE MATO GROSSO - CRC/MT, 2011.

Quantos somos. Disponível em:

<http://www.crcmt.org.br/site/novo/registro_quantos_3.php>

Acesso em 23/03/2012

COSER, Clair. A atuação da mulher contabilista nas organizações contábeis de

Florianópolis. Disponível em: <http://tcc.bu.ufsc.br/Contabeis294519.PDF> Acesso em 07/04/2012.

CRUZ, Débora Andrade Teixeira da; MENESES, Karla Regina; PARANHYBUNA, Marisa Favareto; SIERRA, Vanessa Pulheis. Responsabilidade, honestidade e conduta do profissional contábil: uma discussão dialética, tendo por base o caso Schincariol. Disponível em: 〈http://intertemas.unitoledo.br/revista/index.php/Juridica/article/view/537/533>

Acesso em 10/10/2011.

FARI, Murilo Arthur, NOGUEIRA, Valdir. Perfil do profissional contábil: relações entre formação e atuação no mercado de trabalho. Revista Perspectiva Contemporânea, Campo Mourão, v.2, n.1, p. 117-131, janeiro / junho 2007.

FARIA, Norma Candido. Ética profissional do contabilista: um meio de valorização do profissional contábil. Disponível em

<http://www.biblioteca.ajes.edu.br/arquivos/monografia_20110913204007.pdf. >

Acesso em 24/03/2012.

FIPECAFI - Fundação Instituto de Pesquisas Contábeis, Atuariais e Financeiras. Ética geral e profissional em contabilidade - 2 ed. - São Paulo: Atlas, 1997.

FONTES, Cleverson Luiz, BATISTA, Halcima Melo. Ética na docência: um estudo nas instituições de ensino superior de Natal / RN. Contabilidade Vista \& Revista. Belo Horizonte, v.16, n.1, p 9-30, abril/2005.

FORTES, José Carlos. Manual do Contabilista: Uma abordagem teórico-prática da profissão contábil - São Paulo: Saraiva 2005.

GIL, Antônio Carlos. Métodos e técnicas de pesquisa social. 5. Ed. São Paulo: Atlas, 1999.

GIL, Antônio Carlos. Como Elaborar Projetos de Pesquisa. 4 ed. São Paulo: Atlas, 2002.

GODOY, Arilda S. Introdução à pesquisa qualitativa e suas possibilidades. Revista de Administração de Empresas, v. 35, n. 2, Mar./Abr. 1995a, p. 57-63.

IUDÍCIBUS, Sérgio de; MARION, José Carlos. Introdução à teoria da contabilidade: para o nível de graduação. 2. ed. São Paulo: Atlas, 2000.

KRAEMER, Maria Elisabeth Pereira. Ética, sigilo e o profissional contábil, Contabilidade Vista \& Revista, Belo Horizonte, v.12, n. 2, p. 33-48, agosto 2001.

MARION, José Carlos, ALMEIDA, Fabio da Silva e, VALVERDE, Vicente Sebastião. A profissão contábil está em crise? Uma opinião sobre os constantes questionamentos sobre a profissão contábil. Contabilidade Vista \& Revista, Belo Horizonte, v.13, n. 2, p. 85-98, agosto 2002.

MARION, José Carlos, SANTOS, Márcia Carvalho dos. Os dois lados de uma profissão. Contabilidade Vista \& Revista, Belo Horizonte, v.11, n. 2, p. 3-9, agosto 2000.

MARION, José Carlos. Contabilidade empresarial. São Paulo: Atlas, 1998.

MARION, José Carlos. Preparando-se para a profissão do futuro. Contabilidade Vista \& 
Percepção dos contabilistas dos escritórios de contabilidade de Tangará da Serra - MT em relação à ética e o reconhecimento da classe contábil

Revista - Belo Horizonte, v.9, n. 1, p 14-21, março/1998.

MOURA, Iraildo José Lopes de, FONSECA, Teodomiro Oliveira, DIAS, Geisa Maria Almeida. Papel do contador no mercado globalizado. Disponível em: <http://iraildojose.sites.uol.com.br/globalizacao.html> Acesso em: 07/04/2012.

NALINI, José Renato. Ética geral e profissional / José Renato Nalini. - 3 ed. rev. e ampl. São Paulo: Editora Revista dos Tribunais, 2001.

OLIVEIRA, Silvio Luis de. Tratado de metodologia científica: projetos de pesquisa, TGI, TCC, monografias, dissertações e teses. $2^{a}$ ed. São Paulo: Pioneira, 2000.

PESSOA, Mônica da Silva. Ética - uma abordagem geral e aplicada na contabilidade e na auditoria. Disponível em:

<http://www.avm.edu.br/monopdf/30/M\%C3\%94NICA\%20DA\%20SILVA\%20PESSOA.pdf $>$. Acesso em: 13/09/2011

RODRIGUES, Ana Kátia da Silva. O profissional contábil e as exigências do mercado de trabalho no município de Juína. Disponível em:

〈http://www.biblioteca.ajes.edu.br/arquivos/monografia_20110809162110.pdf $>$

Acesso em 07/04/2012.

SÁ, Antônio Lopes. Ética profissional. 3. Ed. São Paulo: Atlas 2000.

SANTOS, Dilcilene Aparecida Neves, ASSIS, Gilcélia Glória de, ALVES, Luiz Gustavo Ferreira. O papel da ética na valorização do profissional contábil. Disponível em:

$<$ http://univen.noip.biz/listamono/monografias/Ciências\%20Contábeis/2009/O\%20PAPEL\%20DA\%20ÉTICA \%20NA\%20VALORIZACCÃO\%20DO\%20PROFISSIONAL\%20CONTÁBIL.pdf> Acesso em: 15/07/2011

SILVA, Solange Maria da, PEREIRA, Anísio Candido, RODRIGUES, Gregorio Mancebo, PENHA, José Carlos, GIACOMAZI, Luiz Cesar, MARCOLINO, Osmir. A ética e o profissional de contabilidade no novo milênio. In: XXXIX Asamblea Anual del Consejo Latinoamericano de Escuelas de Administración, Puerto Plata, Cladea, 2004.

SIQUEIRA, Leonardo B. de. Profissionalismo: uma análise da ética contábil. Veredas Favip - Caruaru, Vol. 2, n. 01, pp. 70-77, jan./jun. 2005.

SOARES, Moisés Souza. Ética e exercício profissional. - 2 ed. rev. e atualizada. - Brasília Abeas, 2000.

STUKART, Hebert Lowe. Ética e corrupção, os benefícios da conduta ética na vida pessoal e empresarial - São Paulo: Nobel, 2003.

VALGAS, Lanúsia. A percepção dos contabilistas acerca do grau de conhecimento e respeito ao código de ética do contabilista. Disponível em:

<http://tcc.bu.ufsc.br/Contabeis294330> Acesso em 07/04/2012. 